MEDFARM: Jurnal Farmasi dan Kesehatan, Vol 10, No 1, 2021, Hal. 18-27

e-ISSN : 2715-9957

p-ISSN: 2354-8487

\title{
PENGARUH KOMUNIKASI TENTANG VAKSIN SINOVAC TERHADAP KESADARAN MASYARAKAT DI DESA JEMBRAK KABUPATEN SEMARANG
}

\author{
Liya Virdha Handayani ${ }^{1}$, Nihlatin Azka ${ }^{2}$, Sovie Novia Wijayanti ${ }^{3}$, Riszki Nur \\ Ainii $^{4}$, Rusmiati ${ }^{5}$, Aris Prio Agus Santoso ${ }^{6}$ \\ 1,2,3,4,5,6) Universitas Duta Bangsa Surakarta \\ e-mail: \\ rusmia@gmail.com
}

\begin{abstract}
ABSTRAK
Dunia Kesehatan tidak akan lepas dari aktivitas komunikasi kelompok, termasuk pengaruh komunikasi tentang Vaksin Sinovac terhadap kesadaran masyarakat, ada beberapa pihak masyarakat yang mempersoalkan atau meragukan keamanan dan kehalalan Vaksin Sinovac, jadi banyak sekali masyarakat yang belum tau tentang Vaksin Sinovac dan masih takut untuk menggunakannya, karena itu masyarakat kurangnya informasi yang benar atau kurangnya kesadaran komunikasi tentang vaksin sinovac yang dapat memutus rantai penyebaran covid-19. Permasalahan dalam penelitian ini adalah bagaimana peran tenaga kesehatan dalam memberikan edukasi kepada masyarakat terhadap pentingnya Vaksin Sinovac. Metode penelitian ini menggunakan metode survey dengan cara membuat Kuisioner menggunakan google form kemudian disebarkan kepada masyarakat. Bentuk penelitian ini bersifat persuasif yang bertujuan agar mendapatkan gambaran dari perumusan masalah. Data yang digunakan bersumber dari data sekunder yaitu data yang diperoleh dari literatur-literatur, serta teknik analisis data dalam penelitian ini menggunakan teknik analisis kualitatif. Berdasarkan hasil penelitian yang diperoleh bahwa sangat minim sekali kesadaran pemahaman masyarakat mengenai vaksinasi dan masih banyak masyarakat yang takut akan jika divaksin takut efek samping yang akan ditimbulkan jika disuntik Vaksin Sinovac.
\end{abstract}

Kata kunci : vaksin sinovac, masyarakat, covid-19

\section{ABSTRAK}

The world of health will not be separated from the communication activities of the group, including the influence of communication about the Sinovac Vaccine on the awareness of the community, there are some people who question or doubt the safety and halalness of the Sinovac Vaccine, so a lot of people who do not know about the Sinovac Vaccine and are still afraid to use it, therefore the public lacks the correct information or lack of awareness of communication 
MEDFARM: Jurnal Farmasi dan Kesehatan, Vol 10, No 1, 2021, Hal. 18-27

e-ISSN : 2715-9957

p-ISSN: 2354-8487

about the sinovac vaccine that can break the chain of dissemination of covid-19. The problem in this ppenelitian is the role of health workers in providing education to the public on the importance of the Sinovac Vaccine. This research method uses the survey method by creating questionnaires using google form and then disseminated to the public. This form of research is persuasive in order to get an idea of the formulation of problems. The data used is sourced from secondary data, namely data obtained from literature, as well as data analysis techniques in this study using qualitative analysis techniques. Based on the results of the research obtained that there is very little awareness of public understanding of vaccination and there are still many people who are afraid if vaccinated fear the side effects that will be caused if injected Sinovac Vaccine.

Keywords: sinovac vaccine, community, covid-19

\section{PENDAHULUAN}

Komunikasi adalah proses pengoperasian rangsangan (stimulus) dalam bentuk lambang atau simbol bahasa atau gerak (non verbal), untuk mempengaruhi perilaku orang lain. Stimulus atau rangsangan ini dapat berupa suara atau bunyi atau bahasa lisan, maupun berupa gerakan, tindakan atau simbol-simbol yang diharapkan dapat dimengerti oleh pihak lain, dan pihak lain merespon atau bereaksi sesuai dengan maksud pihak yang memberikan stimulus

Menurut Liliweri (2008), komunikasi dapat diartikan sebagai pengalihan suatu pesan dari satu sumber kepada penerima agar dapat dipahami. Proses komunikasi biasanya melibatkan dua pihak, baik antar individu dengan individu, individu dengan kelompok atau antar kelompok dengan kelompok yang berinteraksi dengan aturan-aturan yang disepakati bersama.Komunikasi kesehatan merupakan bagian dari komunikasi antar manusia yang memiliki fokus pada bagaimana seorang individu dalam suatu kelompok atau masyarakat menghadapi isu-isu yang berhubungan dengan kesehatan serta berupaya untuk memelihara kesehatannya (Northouse dalam Notoatmodjo, 2005). Fokus utama dalam komunikasi kesehatan adalah terjadinya transaksi yang secara spesifik berhubungan dengan isu-isu kesehatan dan faktor-faktor yang mempengaruhi transaksi tersebut. Transaksi yang berlangsung antar ahli kesehatan, antara ahli kesehatan dengan pasien dan antara pasien dengan keluarga pasien merupakan perhatian utama dalam komunikasi kesehatan. 
MEDFARM: Jurnal Farmasi dan Kesehatan, Vol 10, No 1, 2021, Hal. 18-27

e-ISSN : 2715-9957

p-ISSN: 2354-8487

Kesehatan pada dasarnya menyangkut semua kehidupan, baik kehidupan perseorangan, keluarga, kelompok manusia, masyarakat luas maupun bangsa. Untuk menghasilkan generasi penerus yang cerdas, sehat, dan berkualitas, perlu disiapkan sejak dalam kandungan dan dijaga sejak lahir. Berbagai upaya telah dilakukan oleh pemerintah dengan menyediakan pelayanan kesehatan dan peningkatan peran serta masyarakat dalam upaya pembangunan kesehatan. Menciptakan kualitas penduduk khususnya di bidang kesehatan, tidak hanya mempertimbangkan aspek fisik atau mental saja, tetapi juga memperhatikan dan mempertimbangkan dari aspek dan produktifitasnya (mempunyai pekerjaan atau menghasilkan secara ekonomi). Karena kesehatan sifatnya holistik artinya saling mempengaruhi dalam mewujudkan tingkat kesehatan seseorang, kelompok atau masyarakat.

Berdasarkan data Kementerian Kesehatan, yang dipublikasikan Humas BNPB, Selasa (26/1/2021), total kumulatif kasus Corona di Indonesia berjumlah 1.012.350. Adapun tiga besar penyumbang kasus berturut-turut adalah Jawa Barat menyumbang 3.924 kasus baru positif Corona, kemudian DKI Jakarta (2.314 kasus) dan Jawa Tengah (1.678 kasus). Selain tiga provinsi tersebut, dilaporkan bahwa seluruh provinsi di Indonesia mencatat temuan kasus baru. Dilaporkan bahwa secara kumulatif sebanyak 820.356orang sembuh dari Covid 19 dan sebanyak 28.468 pasien Covid yang meninggal dunia. Dalam rangka memutus penularan Covid 19 pemerintah Indonesia juga akan melakukan vaksinasi kepada penduduk Indonesia. Menurut Fundrika, B.A.(2021). Pemerintah Indonesia disebut telah membuat peta jalan untuk vaksinasi Covid-19 di Indonesia. Menteri Kesehatan Budi Gunadi Sadikin, menyebutkan bahwa rencana vaksinasi di Indonesia akan dilakukan dalam dua periode. Hal tersebut sudah dikonsutasikan kepada Indonesian Technical Advisory Group on Immunization (ITAGI) yang bertugas memberikan nasehat atau advice kepada Menteri Kesehatan. Periode pertama akan dimulai pada Januari sampai dengan April 2021.

Menurut Aco, H. (2020) berdasarkan Keputusan Menteri Kesehatan Nomor H.K.01.07/Menkes/9860 /2020 tentang Penetapan jenis Vaksin untuk Pelaksanaan Vaksinasi Corona Virus Disease (Covid 19) diketahui bahwa telah ditetapkan enam 
MEDFARM: Jurnal Farmasi dan Kesehatan, Vol 10, No 1, 2021, Hal. 18-27

e-ISSN : 2715-9957

p-ISSN: 2354-8487

jenis vaksin untuk proses vaksinasi di Indonesia. Adapun jenisnya adalah vaksin yang produksi oleh P.T. Bio Farma (persero), Astra Zeneca, China National Pharmaceutical Group Corporation (Sinopharm), Moderna, Pfizer- BioNTech, dan Sinovac Biotech Ltd. Pemerintah telah mendatangkan vaksin Covid 19 sebanyak 3 juta dari produsen Sinovac dari China dalam dua tahap, yaitu sebanyak 1,20 juta dosis sebagai tahap pertama pada 06 Desember 2020 dan tahap ke dua adalah sebesar 1,80 juta dosis pada 31 Desember 2020 (Nareza, M., 2021). Pemerintah menurut Ketua Komite Penanganan Covid-19 dan Pemulihan Ekonomi Nasional Hartarto,merencanakan segera memulai untuk melakukan vaksinasi yang dijadwalkan sekitar pertengahan bulan Januari, dalam keterangan yang disampaikan melalui tayangan YouTube Sekretariat Presiden. Shalihah, N.F. \& Nugroho, R.S. (2021). Pada saat ini perlombaan untuk memproduksi vaksin diawali oleh China dengan Sinovac dan Sinopharm. Perusahaan biofarmasi yang berkedudukan di Beijing China tersebut mendukung pemanfaatan CoronaVac yaitu vaksin yang tidak aktif. Vaksin tersebut bekerja dengan menggunakan virus yang sudah dimatikan guna merangsang system kekebalan tubuh terhadap virus tanpa risiko memberikan respon terhadap penyakit yang serius. CoronaVac adalah metode vaksin yang lebih tradisional seperti digunakan pada banyak vaksin diantaranya adalah vaksin rabies. Hal tersebut diungkapkan oleh Associate Professor Luo Dahai dari Nanyang Technological University kepada BBC.

Vaksin Sinovac telah menjalani uji coba fase tiga di berbagai Negara. Data sementara dari uji coba tahap akhir di Turki dan Indonesia menunjukkan bahwa vaksin tersebut efektif masing-masing sebesar 91,25\% dan 63,50\% . Para peneliti di Brasil pada awalnya mengatakan dalam uji klinis mereka efektifitas vaksin Sinovac adalah $78 \%$, akan tetapi setelah dilakukan penambahan data penelitian maka angka tersebut direvisi menjadi 50,40\% dan dideklarasikan pada bulan Januari 2021. Vaksin Sinovac telah disetujui untuk penggunaan darurat pada kelompok berisiko tinggi di China sejak Juli 2020, dan pada September 2020 Sinovac telah diberikan kepada 1.000 orang sukarelawan denga hasil kurang dari 5\% merasakan tidak nyaman atau kelelahan ringan (Yvette Tan, 2021). 
MEDFARM: Jurnal Farmasi dan Kesehatan, Vol 10, No 1, 2021, Hal. 18-27

e-ISSN : 2715-9957

p-ISSN: 2354-8487

Contoh permasalahan yang muncul di masyarakat adanya vaksin sinovac antara lain:

1. Masyarakat masih meragukan keamanan vaksin dan ada beberapa pihak masyarakat yang mempersoalkan kehalalan vaksin sinovac.

2. Ada beberapa masyarakat masyarakat yang memegang tinggi nilai bahwa memasukkan cairan vaksin kedalam tubuh dilarang oleh kepercayaan nya

3. Masyarakat menolak vaksin biasanya berusaha untuk menyampaikan aspirasi atau sudut pandang mereka terhadap orang lain dan berupaya agar orangorang disekitarnya tetap aman.

\section{METODOLOGI PENELITIAN}

\section{Metode Survey}

Metode penelitian yang digunakan dalam penelitian ini menggunakan medote penelitian survey. Dalam metode survey, sumber data atau informasi utamanya diperoleh dari responden sebagai sampel penelitian dengan menggunakan angket atau kuisioner sebagai intrumen pengumpulan data yang didistribusikan secara langsung atau melalui perantara seperti telepon atau media online.

\section{Bentuk Penelitian}

Bentuk penelitian ini adalah persuasif yang bertujuan untuk mengembalikan keyakinan masyarakat terhadap pentingnya vaksinasi, meningkatkan pengetahuan tentang kesehatan dan vaksinasi Covid-19, serta kesadaran dan kepedulian seluruh masyarakat dalam pencegahan dan pengendalian Covid-19 agar dapat memutus rantai penyebaran virus.

\section{Teknik Pengumpulan Data}

Data yang digunakan dalam penelitian ini bersumber pada data primer dan sekunder yaitu data yang diperoleh dari laporan penelitian, artikel, website dan lain-lain yang terkait dengan perundang-undangan.

\section{Analisis Data}

Teknik analisis data dalam penelitian ini menggunakan teknik analisis kualitatif, yaitu metode yang lebih menekankan pada aspek pemahaman secara mendalam terhadap suatu masalah dari pada melihat permasalahan untuk penelitian 
MEDFARM: Jurnal Farmasi dan Kesehatan, Vol 10, No 1, 2021, Hal. 18-27

e-ISSN : 2715-9957

p-ISSN: 2354-8487

generalisasi. Adapun analisis kualitatif dalam penelitian ini digunakan untuk menjawab bagaimana pencegahan dan kebijakan yang diambil pemerintah negara Indonesia untuk memutus rantai penyebaran pandemi Covid-19 di Indonesia dan peran tenaga kesehatan dalam memberikan edukasi kepada masyarakat terhadap pentingnya vaksin sinovac.

\section{HASIL DAN PEMBAHASAN}

Sebagai upaya penanganan pandemi virus corona atau Covid-19 yang tak kunjung reda, banyak lembaga penelitian dan produsen vaksin di seluruh dunia berlomba-lomba mengembangkan vaksin Covid-19. Vaksin memiliki manfaat sebagai upaya mencegah penyakit menular. Sebab, vaksin dapat memberikan tubuh pertahanan dan perlindungan dari berbagai penyakit infeksi yang berbahaya. Untuk itu, pemerintah melakukan pemberian vaksin untuk melindungi masyarakat terhadap penyakit-penyakit menular.

Menurut Kristoforus, vaksinasi memang telah dinobatkan oleh WHO dan CDC sebagai salah satu upaya pencegahan terbaik dalam bidang kesehatan masyarakat. Vaksinasi telah mendapat perhatian publik dan diperbincangkan banyak orang, terutama sejak viralnya kabar terkait vaksin Covid-19. Kesadaran dan pengetahuan masyarakat akan pentingnya vaksinasi juga semakin meningkat.

Deputi Bidang Koordinasi Peningkatan Kualitas Kesehatan dan Pembangunan Kependudukan Kemenko PMK Agus Suprapto menyampaikan, situasi pandemi Covid-19 membutuhkan kemitraan berbagai pihak dan kesiapan sumber daya manusia pendukungnya. Deputi Agus menyatakan, tenaga kesehatan masyarakat sangat perlu dilibatkan secara optimal dalam banyak aspek promotif dan preventif kesehatan masyarakat. Para tenaga kesehatan masyarakat bisa berinovasi dan menciptakan strategi percepatan penanganan Covid-19 di Indonesia, dengan fokus utama edukasi dan berdayakan masyarakat dan fokus kedua perkuat pelayanan Kesehatan.

Saat ini waktu yang paling tepat menambah serta menyegarkan kembali pengetahuan para tenaga medis, terutama dokter, pentingnya edukasi mengenai 
MEDFARM: Jurnal Farmasi dan Kesehatan, Vol 10, No 1, 2021, Hal. 18-27

e-ISSN : 2715-9957

p-ISSN: 2354-8487

vaksinasi, dan mencegah hesitansi. Para dokter harus bisa menjadi frontline educators dan trusted source of information demi masyarakat Indonesia yang sehat. Dengan terus berkomitmen untuk mendukung pemerintah dalam upaya pencegahan penyebaran Covid-19, para tenaga kesehatan harus terus memberikan informasi dan edukasi mengenai pentingnya vaksinasi Covid-19 sebagai salah satu cara tercepat berakhirnya pandemi Covid-19. Sangat penting untuk meningkatkan pengetahuan tentang kesehatan dan vaksinasi Covid-19, kesadaran dan kepedulian seluruh masyarakat dalam pencegahan dan pengendalian Covid-19.

Peran tenaga kesehatan sebagai ujung tombak mengedukasi masyarakat, juga harus bisa mengembalikan keyakinan masyarakat terhadap pentingnya vaksinasi. Termasuk meningkatkan penerimaan masyarakat terhadap vaksinasi Covid-19. Para dokter dan tenaga medis perlu menyuarakan bahwa vaksinasi itu sangat penting untuk mencegah penyakit-penyakit yang sudah ada. Ini penting dilakukan agar setelah pandemi Covid-19 berakhir, tidak muncul wabah penyakit-penyakit lain. Oleh karena itu, diperlukan adanya update informasi mengenai berbagai hal yang berkaitan dengan vaksinasi di era pandemi bagi para dokter se-Indonesia.

Meski Badan Pengawas Obat dan Makanan (Badan POM) telah menyatakan vaksin Covid-19 Sinovac ini aman dan efikasinya melampaui standar Organisasi Kesehatan Dunia (WHO), masih ada yang ragu untuk menjalani vaksinasi. Oleh karena itu, pemerintah mengedepankan cara persuasif mengenai hal tersebut dengan melakukan edukasi ke masyarakat menyangkut program vaksinasi Covid-19. Diskusi dan sosialisasi saat ini gencar dilakukan kepada para tenaga kesehatan yang saat ini menjadi kelompok prioritas vaksinasi tahap awal. Dengan dukungan dari semua pihak maka program penanggulangan covid-19 di Indonesia akan berjalan dengan baik, sukses dan berdampak pada baik pada penurunan jumlah kasus covid-19

Di samping itu, beragam informasi hoaks mengenai vaksin juga beredar di tengah masyarakat. Untuk itu, masyarakat juga perlu memahami setiap informasi yang didapatkannya. Kenali, ciri-ciri berita yang tidak benar, dan apabila ragu, tanyakan langsung kepada ahlinya, seperti dokter dan para pakar mengenai vaksin yang terpercaya. 
MEDFARM: Jurnal Farmasi dan Kesehatan, Vol 10, No 1, 2021, Hal. 18-27

e-ISSN : 2715-9957

p-ISSN: 2354-8487

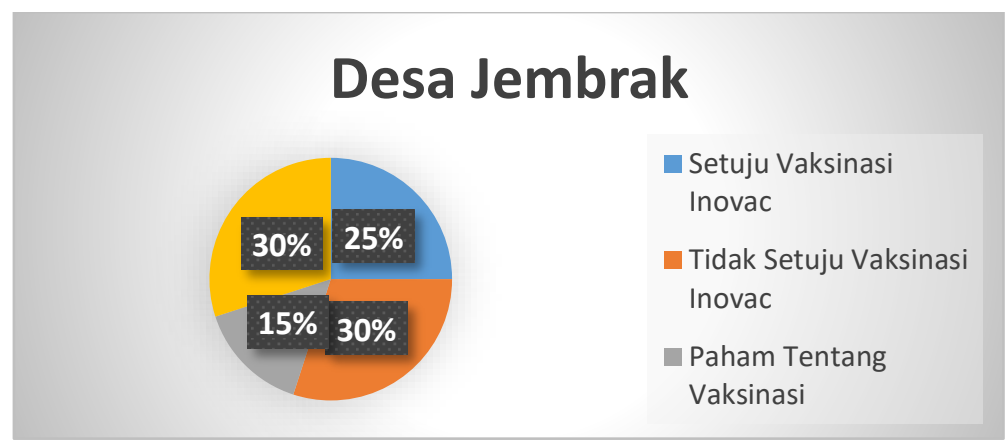

Gambar 1. Pengaruh Komunikasi Tentang Vaksin Sinovac Terhadap Kesadaran Masyarakat Di Desa Jembrak Kabupaten Semarang

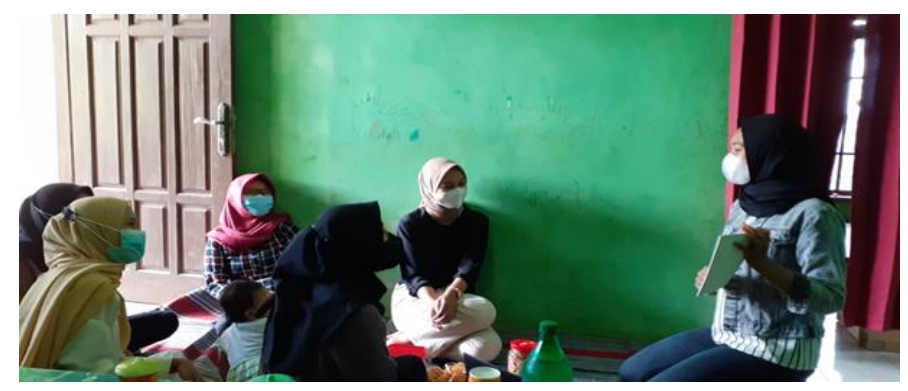

Gambar 2. Sosialisasi di desa Jembrak Sosialisasi komunikasi mengenai vaksin sinovac di Desa Jembrak

Diagram diatas menunjukan data hasil penelitian menggunakan kuesioner yang disebarkan ke masyarakat Desa Jembrak. Walaupun belum semua masyarakat yang paham dan mengerti betapa pentingnya vaksinasi namun diharapkan dengan penelitian ini masyarakat dapat mendapat informasi yang jelas mengenai pentingnya vaksinasi untuk memutus rantai penyebaran Covid-19. Peran tenaga kesehatan dan pemerintah akan edukasi kepada masyarakt mengenai vaksinasi masih sangat dibutuhkan. Oleh karena itu sebaiknya kita sebagai mahasiswa Fakultas Ilmu Kesehatan sebaiknya berperan penting akan hal ini, dengan cara memberikan 
MEDFARM: Jurnal Farmasi dan Kesehatan, Vol 10, No 1, 2021, Hal. 18-27

e-ISSN : 2715-9957

p-ISSN: 2354-8487

informasi pada keluarga, kerabat, maupun tetangga dan orang yang mungkin sangat membutuhkan edukasi tentang vaksinasi.

Dari data diatas dapat disimpulkan bahwa sangat minim sekali pemahaman masyarakat mengenai vaksinasi. Masih banyak masyarakat yang takut jika divaksin, takut akan efek samping yang akan ditimbulkan jika disuntik Vaksin Sinovac.

\section{SIMPULAN}

Setelah meneliti mengenai pengaruh komunikasi tentang vaksin sinovac terhadap kesadaran masyarakat penulis menyimpulkan bahwa:

1. Usaha para tenaga kesehatan untuk memberikan informasi dan edukasi mengenai pentingnya vaksinasi Covid-19 sangat penting untuk meningkatkan pengetahuan tentang kesehatan dan vaksinasi Covid-19. Vaksin Sinovac telah menjalani uji coba fase tiga di berbagai Negara. Data sementara dari uji coba tahap akhir menunjukkan bahwa vaksin tersebut efektif mencegah penyakit ini dan dapat diterima keamannya .

2. Masyarakat perlu memahami setiap informasi yang didapatkannya,beragam informasi hoaks atau tidak benar mengenai vaksin juga beredar di tengah masyarakat sehingga masyarakat harus bijak dalam memilih-milih berita. Kenali ciri-ciri berita yang hoaks atau tidak benar, dan apabila ragu, tanyakan langsung kepada ahlinya, seperti dokter dan para pakar mengenai vaksin yang terpercaya.

\section{DAFTAR PUSTAKA}

Wardani, T.S dkk. 2021, Pengantar Komunikasi Kesehatan, Jakarta: Trans Info Media.

Santoso, A.P dkk. 2020, Etika Profesi Kefarmasian dan Hukum Kesehatan, Jakarta: Trans Info Media.

Aris Prio Agus Santoso, dan Widi Nugrahaningsih, 2021, Alternatif Penyelesaian Sengketa, Yogyakarta: Pustaka Baru.

Aris Prio Agus Santoso, 2020, Hukum Kesehatan, Yogyakarta: Pustaka Baru.

Aris Prio Agus Santoso, 2020, Hukum Kesehatan, Jakarta: Trans Info Media. 
MEDFARM: Jurnal Farmasi dan Kesehatan, Vol 10, No 1, 2021, Hal. 18-27

e-ISSN : 2715-9957

p-ISSN: 2354-8487

Kresna Agung P, dan Aris Prio Agus S, 2021, Konsep Dasar Logika dan Psikologi Hukum, Yogyakarta: K-Media.

Aris Prio Agus Santoso, dan Tatina Siska Wardani, "Analisis Yuridis Kewenangan Perawat dalam Pemberian Obat-Obatan Label Merah pada Praktik Keperawatan Mandiri", Yurisprudentia: Jurnal Hukum Ekonomi, Vol. 6, No.1, 2020.

Aris Prio Agus Santoso, dkk, "Legal Protection of Health Worker in The Task Force for The Acceleration of Handling Covid-19 from a State Administrative Law Point ov View", Jurnal Ilmu Sosial dan Pendidikan, Vol.5, No. 1, 2021.

Aris Prio Agus Santoso, dan Erna Chotidjah Suhatmi, 2021, "Pemutusan Hubungan Kerja di Tengah Pandemi Covid-19 Ditinjau dari Sudut Pandang Hukum Ketenagakerjaan", UNIFIKASI: Jurnal Ilmu Hukum, Vol. 8, No. 1, 2021.

Bacter, L., Nichole E., Ho, Evelyn, 2008. Everyday Health Communication Experiences. Journal of American College Health. Vol. 56 No. 4.

Humaniora. 2020. Tenaga Medis Ujung Tombak Edukasi Pentingnya Imunisasi. Jakarta : Media Indonesia

Kemenko PMK. 2020. Pentingnya Peran Tenaga Kesehatan Masyarakat dalam Penanganan Covid-19. Jakarta : Deputi 3

Liliweri, Alo. 2008. Dasar-dasar Komunikasi Kesehatan. Jakarta : Pustaka Pelajar

Mubarak dan Chayatin, 2008 Ilmu Kesehatan Masyarakat : Teori dan Aplikasi. Jakarta : Penerbit Salemba Medika 